\title{
PREDICAREA EVANGHELIEI ŞI CONSTITUIREA DE BISERICI LOCALE, SCOPURI IMEDIATE ALE MISIUNII
}

\author{
Aurel Pavel ${ }^{*}$
}

\begin{abstract}
This study exposes two of the immediate goals of mission: preaching the Gospel and the establishment of local churches.They were followed, even from the beginning of the Church by the Holy Apostles, the ones sent to mission by our Savior Jesus Christ.

Contemporary Orthodox theology has kept valid all these purposes, as the work of one of the greatest Orthodox missionary theologians of the twentieth century, Reverend Professor Ion Bria, demonstrates. In the end I have shown that there are certain conditions that must be complied for the Orthodox mission to be successful in achieving its goals.
\end{abstract}

Key words: Orthodox mission, preaching the Gospel, local Church, Ion Bria.

Gândirea teologică ortodoxă despre misiune nu a fost niciodată dezvoltată într-un mod sistematic, recunoaştea fără ezitare într-una din lucrările sale actualul arhiepiscop al Albaniei, Anastasios Yannoulatos. Acest fapt se diferențiază de gândirea apuseană, preocupată mai mult timp cu expunerea scopului şi motivului misiunii. A vorbi despre misiune din punct de vedere ortodox presupune un pericol dublu: fie a ne limita la repetarea ideilor altora, după ce studiem concepțiile catolice şi protestante, fie a completa pe acestea două, în sensul de a crea ceva total distinct de ele. A treia cale, mai serioasă, mai modestă, este cea corectă: a evita tactica

\footnotetext{
* PhD Professor at "Sf. Andrei Şaguna" Faculty of Theology from the University "Lucian Blaga" in Sibiu, Romania.
} 
controversei şi a medita asupra soteriologiei, eclesiologiei şi eshatologiei ortodoxe dintr-o perspectivă misionară ${ }^{1}$.

Această opinie am avut-o în minte când am lucrat la editarea unor studii mai puțin cunoscute ale unuia dintre cei mai de seamă teologi misionari ortodocşi din secolul al XX-lea, Pr. Prof. Ion Bria

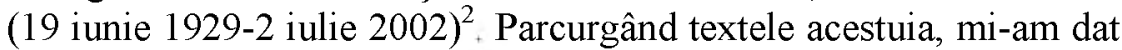
seama că reflecțiile critice ale arhiepiscopului Yannoulatos nu sunt în totalitate valide; probabil că intenția sa era una de a provoca pe teologii actuali la reflecție asupra naturii şi specificului misiunii ortodoxe, convins fiind că, deşi a avut necontenit o ,conştiinţă misionară"'- dovedită de activitatea sa - Biserica Ortodoxă nu a fost în mod special preocupată de dezvoltarea unui ,sistem misionar”, a unei „baze teoretice misionare". Pe de altă parte, în studiul de față ne dorim să arătăm că niciodată nu a lipsit de la teologii ortodocşi o evidențiere a ceea ce este şi are ca scop misiunea. Ca dovadă vom recurge chiar la punctarea unor teme esențiale din gândirea teologului român amintit, fără a avea nicio pretenție exhaustivă. Pentru noi este important să ilustrăm de ce misiunea a urmărit ca scopuri imediate două principii fundamentale: predicarea Evangheliei şi extinderea Bisericii „la toate neamurile”, ca cerință intrinsecă a poruncii Mântuitorului de a face misiunea (Mt. 24, 28).

Hristos, Dumnezeu-Omul este taina originară şi atotcuprinzătoare a mântuirii noastre, fiindcă în El ne-a fost dată baza unirii divinului cu umanul. Adevărul fundamental care stă la baza Bisericii este acesta: trupul şi firea noastră au fost asumate de Unul din Treime. Biserica, în calitatea ei de aşezământ divino-uman, este o consecință directă a uniunii ipostatice din Hristos. Căci dacă Fiul lui Dumnezeu a luat trupul nostru, S-a unit cu el, îl modelează şi îl sfințeşte din interior, prin aceasta transformând firea umană pe care şi-a făcut-o proprie, actualizând-o şi personalizând-o, toate acestea

${ }^{1}$ Archbishop Anastasios Yannoulatos, Mission in Christ's Way. An Orthodox Understanding of Mission, Brookline/Geneva, Holy Cross Orthodox Press/ World Council of Churches Publications, 2010, p. 41.

${ }^{2}$ Ion Bria, Studii de Misiune şi Ecumenism, Sibiu, Editura, Astra Museum, 2013. 
fac posibile refacerea şi restaurarea cosmosului şi redeschiderea perspectivei unirii personale a fiecărui om cu Dumnezeu, actualizarea teandriei în fiecare om în mod conştient şi liber. Aceasta nu este altceva decât extinderea Persoanei lui Hristos în toți cei ce se alipesc de El, adică Biserica.

Citatul scripturistic „aşa cum Tatăl $\mathrm{m}$-a trimis pe mine, tot astfel şi eu vă trimit pe voi” (In. 20, 21), prin care Iisus Hristos i-a trimis pe Sfinții Apostoli în lucrarea misionară, coincide cu „trimiterea” Bisericii în lume, care se referă la un dublu aspect: actul de universalizare a Evangheliei şi de integrare a tuturor oamenilor în condiția mântuitoare a Împărăției lui Dumnezeu. Trimiterea văzută a Fiului şi a Duhului Sfânt în lume, voită şi iniţiată de Tatăl ceresc, reprezintă baza misiunii. Participarea credincioşilor la trimiterea Fiului şi a Duhului Sfânt înseamnă participarea la viața de comuniune a lui Dumnezeu; şi iarăşi, părtăşia de aceasta este sinonimă cu accederea la Împărătia lui Dumnezeu, a cărei anticipare se realizează încă de acum în viaţa de comuniune a Bisericii - Trup mistic al lui Hristos şi templu al Duhului Sfânt ${ }^{3}$.

Predicarea Evangheliei nu este altceva decât lucrarea de vestire a Persoanei şi a operei de mântuire a lui Iisus Hristos, Fiul cel veşnic al lui Dumnezeu întrupat „la plinirea vremii”. Astfel, în Noul Testament prin evanghelie se înțelege „vestea cea bună” sau revelația lui Dumnezeu în persoana şi lucrarea mântuitoare a lui Iisus Hristos, mesajul sau conținutul acestei descoperiri cuprins în predica şi învățătura lui Iisus (vezi Mc. 13, 10, 14, 9 sau Rom. 2, 16), precum şi propovăduirea acestui mesaj (Fil. 4, 3). Evanghelia lui Hristos este „putere a lui Dumnezeu spre mântuirea a tot celui care crede, iudeului întâi şi elinului"' (Rom. 1, 16, cf. Efes. 1, 13, I Cor. 15, 1-2). Dar Evanghelia posedă o dimensiune universală, căci ea este „desăvârşirea nemurii” (Sf. Iganatie, Către Filadelfieni, IX, 2), întrucât reprezintă „vestea fericită a păcii şi iubirii aduse de

\footnotetext{
${ }^{3}$ Ion Bria, Mărturia creştină în Biserica Ortodoxă: aspecte, posibilități şi perspective actuale, în „Glasul Bisericii”, anul XLI, nr. 1-3, 1982, pp. 81-83.
} 
Dumnezeu pe pământ, destinată tuturor, umanităţii întregi, de pretutindeni şi din toate timpurile"4.

Încă de la începutul Bisericii, prin evanghelie s-a înțeles întreaga tradiție orală a predicii lui Iisus Hristos. Consemnată apoi în scris, aceasta a devenit normativă pentru învățătura Bisericii. Astfel, toți „evangheliştii” s-au folosit de forma originală a Evangheliei - adică tradiția orală - căreia Biserica i-a dat o formă definitivă înainte de sfârşitul secolului I. Dar după cum atrage atenția Părintele Bria,

„evangheliş̦tii nu sunt simpli colectori de tradiții, fără o contribuție personală la interpretarea materialului care circula. Ei au un rol important nu numai în ceea ce privește aşezarea materialului după un plan care are în centru pe Iisus Hristos, pentru scopuri misionare şi catehetice, ci şi în ce priveşte interpretarea teologică pe care fiecare scriitor biblic o dă tradiției care îi stă la dispoziție"

La fel cum Mântuitorul Iisus Hristos Însuşi se prezenta în Evanghelii ca fiind ,învățător” - rabbi (Mt. 19, 16; 23, 8; Lc. 9, 49; In. 1, 49), având ca principală misiune predicarea Evangheliei (Mc. $1,38)$, tot aşa şi cei aleşi de El, Apostolii, au de îndeplinit această misiune: „învățătorul vostru este unul: Hristos” (Mt. 23, 10), iar cei doisprezece aleşi de El sunt investiți cu puterea iertării păcatelor (Mt. 18,18 ) şi cu misiunea de a propovădui (Mc. 3, 14-19), pentru a fi „martorii” Săi „până la marginea pământului” (F. Ap. 1, 8).

Şi în ceea ce priveşte conținutul predicii există identitate între mesajul lui Iisus Hristos şi cel al ucenicilor Săi. Pe de o parte, Iisus vorbeşte în sinagogi, angajează discuții în contradictoriu cu cărturarii Legii, foloseşte metoda rabinică de exegeză a Scripturii, dar, pe de altă parte, El nu pregetă să predice în mod public, pe străzi, în case particulare, pe câmp, pe vârful colinelor, pe țărmul lacurilor sau lângă Marea Galileii. Principala deosebire față de învățătura omenească a fariseilor provine însă mai ales din aceea că învățătura

${ }^{4}$ Idem, Dicționar de Teologie Ortodoxă, Ediția a II-a, Bucureşti, EIBMBOR, 1994 , p. 160.

${ }^{5}$ Ibidem, p. 161. 
Sa vine din plinătatea lui Dumnezeu, pe care o vesteşte ca „trimis de Dumnezeu" (In. 3, 34). Aceeaşi calitate de trimişi o au şi Apostolii şi ucenicii acestora, care vestesc „vestea cea bună”, Evanghelia Împărăției lui Dumnezeu (Mt. 4, 23) tuturor oamenilor. De reținut că ei posedă tot un cuvânt „cu putere multă” ca şi cuvintele rostite de Cuvântul veşnic, Fiul lui Dumnezeu Întrupat. Acesta le şi spusese: "Cuvintele pe care vi le-am spus sunt duh şi sunt viaţă" (In. 6, 63). Cuvântul lui Iisus Hristos este plin de adevăr şi de iubire divină (Mc. 1,22 ), iar aceaşi putere o au şi cuvintele propovăduitoare ale ucenicilor Săi: mesajul lor are puterea dumnezeiască de transformare a sufletelor, pentru că în ele oamenii îşi găsesc răspuns la problemele vieții lor spirituale ${ }^{6}$.

Predicarea Evangheliei trebuie însă să urmărească naşterea şi transmiterea dreptei credințe, deoarece regula credinței devine regula vieții. Viața creştină autentică este posibilă numai printr-un act de auto-identificare a fiecărei generații de credincioşi cu practica de totdeauna a Bisericii, prin retrăirea în „comuniunea sfinților” în unitate de gândire şi viaţă cu predecesorii (de aici transmiterea Tradiției ca exigență a misiunii).

Analizând conceptul şi acțiunea de evanghelizare, Părintele Bria arată ca aceasta este „esențială pentru zidirea Bisericii, Trupul lui Hristos în istorie, prin convertirea celor ce acceptă cuvântul lui Dumnezeu ca adevărul ultim"7. În acest sens, putem vorbi de dimensiunea dogmatică a Bisericii misionare, apostolice, trimise în lume de Trimisul Tatălui, Fiul lui Dumnezeu, împreună cu Duhul Său cel Sfânt pentru a face din persoana fiecăruia în condiția ei istorică şi din întreaga comunitate umană loc al prezenței iluminatorii, transfiguratoare şi mântuitoare a lui Dumnezeu. Dar apostolicitatea Bisericii este intim, strâns legată şi de celelalte atribute ale acesteia, respectiv, unitatea, sfințenia şi universalitatea ei. În viața de sfințenie a creștinilor, în unitatea lor eclesială se exprimă

\footnotetext{
${ }^{6}$ Ibidem, p. 161.
}

Idem, Ortodoxia in Europa. Locul spiritualității române, Iași, Editura Trinitas, 1995, p. 193. 
cel mai evident aspectul de mărturie creştină şi de reală mărturisire a lui Dumnezeu care este prin excelență unul de vedere spirituală a Acestuia, de simţire a prezenței tainice a Duhului şi de lucrare cu frică şi cutremur existenţial pentru mântuire. Harul Sfintelor Taine şi, mai ales, unirea euharistică cu Hristos Domnul reprezintă vizualizarea la măsura temporală a eternității Împărăţiei lui Dumnezeu şi constituie temeiul activ şi concret pentru mărturia creştină, suportul spiritual şi material pentru împlinirea poruncilor.

Lucrarea unei noi evanghelizări a Europei, în contextul dificil al instalării unei societăţi postmoderne şi postcreştine, constituie marea provocare a creştinismului, indiferent de confesiune, odată intrat în mileniul al III-lea. Părintele Bria a avut curajul realizării unei radiografieri tăioase a influențelor ateismului şi secularizării în acest spațiu geografic, mai ales în partea sa occidentală, pe care o cunoştea foarte bine. De aceea, el vorbeşte de necesitatea reconstrucției creştinismului, dintr-un adevărat amalgam de paradigme şi alternative religioase concurente ${ }^{8}$. De cele mai multe ori, acestea definesc aspecte ale contra-mărturiei (prozelitismului), fiind ,în contradicție nu numai cu un anumit text din Sfânta Scriptură sau cu o anumită doctrină tradițională, ci cu universalitatea Evangheliei, cu Iisus Hristos într-o viziune cosmică"9. Biserica este condiţia misiunii creştine, instrumentul misiunii şi, mai mult, scopul misiunii şi realizarea misiunii deoarece Biserica face parte din mesajul Evangheliei. Biserica este şi un rezultat al misiunii întrucât Dumnezeu conduce pe oameni la mântuire şi le dăruieşte harul său prin activitatea misionară a Bisericii. Noul Testament a consemnat mai multe imagini şi simboluri care o defineau în perioada apostolică: „poporul lui Dumnezeu” (I Pt. 2,10), „trupul lui Hristos” (Rom. 12, 4, I Cor. 12, 13,27), „,templul lui Dumnezeu” (I Tim. 3, 15, Efes. 2, 19, I Cor. 3, 16), „preoție împărătească” (I Pt. 2, 9) sau „mireasa lui Hristos” (Apoc. 21, 2). Dintre toate acestea, părintele

\footnotetext{
${ }^{8}$ Idem, ,Spre plinirea Evangheliei”. Dincolo de apărarea Ortodoxiei: exegeza si transmiterea Traditiei, Alba Iulia, Editura Reîntregirea, 2002, p. 9.

${ }_{9}^{9}$ Idem, Destinul Ortodoxiei, București, EIBMBOR, 1989, p. 153.
} 
Bria arată că expresia „trupul lui Hristos” exprimă cel mai bine raportul dintre Hristos şi Biserica Sa. După Înviere, Iisus Hristos este Capul Bisericii ce a fost răscumpărată cu însuşi sângele Său ( Fa. 20, 28). El a şi înălțat-o, în umanitatea $\mathrm{Sa}$, de-a dreapta Tatălui, restaurând întreaga creație (Col. 1, 18-19). Biserica posedă o dimensiune hristoforă (vezi Efes. 5, 25-27) pentru că ea trăieşte din puterea lui Hristos cel Înviat şi aşteaptă a doua Sa venire. Reprezentând „semnul” sau sacramentul umanității răscumpărate (Efes. 1, 23), Biserica nu doar că transmite mesajul şi slujirea lui Iisus Hristos ci „prelungeşte” întruparea Sa, astfel încât Hristos nu poate fi întâlnit decât în acest mediu eclesial ${ }^{10}$.

Biserica este sacramentul Împărătiei lui Dumnezeu ajunsă la noi în Iisus Hristos ${ }^{11}$. Întemeiată în ziua Cincizecimii, Biserica participă la sfințenia lui Hristos (Evr. 13, 12) şi are ca model chiar Sfânta Treime. Scopul ei este manifestarea „creației noi” - simbol al împărătiei „,care se coboară din cer învăluită de slava lui Dumnezeu, o realitate nouă care nu se poate explica perfect prin imaginile sau analogiile care există în lume"12. Faptul că Biserica posedă un evident caracter dumnezeiesc nu exclude însă şi aspectul uman, istoric, al ei. Mai exact, Biserica se prezintă ca un organism „teandric”, posedând chiar această dimensiune dublă: divino-umană, vazută-nevăzută. Întrepătrunderea celor două dimensiuni trimite în mod absolut necesar la Persoana Duhului Sfânt. El este „martorul” prin excelență al lui Iisus Hristos (In. 15, 26), şi de aceea Biserica nu poate mărturisi pe Hristos decât în şi prin Duhul Sfânt (1 Cor. 12,3), care este principiul existenței şi vitalității ei (vezi F. Ap. 9, 31).

Prezența neîncetată a Duhului Sfânt în cadrul Bisericii încă de la întemeierea ei relevă şi o altă dimensiune pe care aceasta o posedă: dimensiunea eshatologică (Mt. 25, 1; Mc. 2,1; Apoc. 21, 2). Ea este semnul, parabola şi prezența anticipată a Împărăției lui Dumnezeu. Iarăşi vorbim de o dublă realitate: Biserica pământească,

\footnotetext{
${ }^{10}$ Idem, Dicționar de teologie ortodoxă, p. 55.

${ }^{11}$ Idem, Credința pe care o mărturisim, Bucureşti, EIBMBOR, 1987, p. 121

${ }^{12}$ Idem, Dictionar de teologie ortodoxă, pp. 55-56.
} 
comunitatea de creştini dintr-un anumit loc, este nedespărţită de Biserica cerească sau comuniunea sfinților, fiind astfel un semn profetic al împărăției viitoare ${ }^{13}$.

În simbolul de credinţă niceeo-constantinopolitan se spune: "Cred în comuniunea sfinților". Formând ,un trup în Hristos” (Rom. $12,5)$, creştinii formează o unitate indisolubilă. Nici măcar moartea nu o poate distruge, căci „iubirea niciodată nu trece” (1 Cor. 13, 8), iar prin Botez şi comuniune de har în iubire „unul altuia ne suntem mădulare" (Efes. 4, 25) pentru totdeauna.

Una dintre întrebările fundamentale la care Părintele Bria dă răspuns este aceasta: Cine formează această comuniune a sfinților ${ }^{14}$ ?

${ }^{13}$ Tot aşa cum Biserica a fost prefigurată în Vechiul Testament, tot aici regăsim profeții despre Dumnezeu care va stabili Împărăția Sa veșnică ce se va întinde pe tot pământul (Is. 2, 2, Ier. 31, 31). Aceste profeții sunt dublate de anumite texte din Noul Testament ce precizează că Împărăția este anticipată în Biserică şi că ea este chemată să cuprindă întreaga creație, toate popoarele şi veacurile (Mt. 28, 20, Mc. 16, 15, F. Ap. 1, 8). Vezi Ibidem, p. 56.

${ }^{14}$ Şi o întrebare adiacentă acesteia, dar la fel de fundamentală, este aceasta: în contextul pluriconfesionalismului creștin de astăzi, care este adevărata Biserică a lui Hristos? În pofida unor „acuze” mai mult sau mai puțin directe - ceea ar viza anumite relativizări sau concesii pe care le-ar fi făcut -, Părintele Bria a afirmat cu tărie că Biserica Ortodoxă este adevărata continuatoare a Bisericii apostolice. Astfel, în primul rând, în discuţia despre catholicitatea Bisericilor locale, el subliniază credința ortodoxă în unicitatea Bisericii, Una Sancta, ca fiind miezul eclesiologiei ortodoxe. Din perspectiva sa, modul în care Bisericile locale se raportează la Una Sancta este cheia eclesiologiei ecumenice: „Nu pot exista Biserici (la plural) decât ca manifestări ale Bisericii celei una și adevărate". Pr. Prof. Ion Bria respinge orice viziune a unității Bisericii prin crearea unei organizații mondiale, numită adesea unitate structurală. „Biserica cea una nu poate fi creată prin unificarea tuturor Bisericilor locale și a denominațiilor individuale într-o structură internațională”. Vezi I. Bria (ed.), Jesus Christ - the Life of the World: an Orthodox contribution to the Vancouver theme, Geneva, CEB, 1982, pp. 12-13. Biserica Una Sancta este cea care se manifestă în deplinătatea sa catholică în fiecare Biserică locală, Biserica locală nefiind o parte dintr-o altă realitate numită Biserica Universală, care la rândul ei este înțeleasă uneori ca fiind compusă din Biserici locale. Astfel, în concepția sa, Biserica universală nu este o federaţie de Biserici independente unite ierarhic în scop instituțional și administrativ, ci reprezintă o comuniune de 
Răspunsul este unul direct: mai întâi de toate patriarhii şi prorocii Vechiului Testament, apoi „sfinții”” în sens larg, adică cei botezați, iar în cele din urmă sfinții în sens restrâns. În fruntea tuturor se află cea care a crezut în cuvântul lui Dumnezeu, devenind împreunălucrătoare la întruparea Fiului Omului: Maica Domnului ${ }^{15}$.

Biserici locale autocefale ce posedă unitate internă euharistică şi canonică. Cf. Ovidiu Ioan, „De la ospitalitatea euharistică la comuniune deplină: viziunea ecumenică a Părintelui Bria", în N. Moșoiu (coord.), op. cit., p. 530. Într-un studiu dens, intitulat Sinteză ortodoxă a Teologiei Dogmatice, în „Revista Teologică” vol. 5, nr. 3, 1995, pp. 4-5, Părintele Bria expune sintetic punctele cardinale ale Ortodoxiei: 1) Ortodoxia este legată direct de istoria şi originea creștinismului; 2) Ortodoxia crede că Biserica nedespărțită a primului mileniu constituie un punct de referință esențial pentru refacerea unității creștinilor separați de istorie; 3) Ortodoxia constată că în centrul divergențelor interconfesionale ecumenice stă misterul Bisericii; 4) Pentru ortodocşi unitatea creștină este concepută ca o comuniune de Biserici locale (koinonia) unite prin mărturisirea credinței apostolice transmisă în Tradiție; 5) Ortodoxia este o chestiune de istorie a unui popor în sensul că istoria unei naţiuni nu poate fi înțeleasă fără istoria unei Biserici locale. Printr-o astfel de viziune, Ortodoxia are de jucat un rol esențial în cadrul Mişcării Ecumenice. Totuşi, această convingere puternică nu-1 atrage pe Părintele Bria în capcana unui triumfalism ieftin: el ,arată că Biserica - Una Sancta nu poate fi concepută fără ortodocşi, dar nici nu este proprietatea ortodocşilor”. Cf. Cristinel Ioja, „Părintele Profesor Ion Bria şi contribuția sa specifică în elaborarea unei Teologii Dogmatice", în N. Moşoiu (coord.), op. cit., p. 327; Mihai Iosu, „Părintele Profesor Ion Bria. Demersuri şi soluții pastorale”, în Ibidem, p. 376; David Pestroiu, „Părintele prof. dr. Ion Bria - misionar al Ortodoxiei", în Ibidem, p. 441.

${ }^{15}$ I. Bria, Tratat de teologie dogmatică şi ecumenică, p. 167. Despre Maica Domnului, Ion Bria scria că este unul „din subiectele preferate ale imnologiei și poeziei liturgice", aducând ca exemplu rugăciunea de mijlocire ce este rostită după prefacerea darurilor euharistice. Dintre aspectele cele mai importante ale mariologiei ortodoxe sunt: cooperarea la Taina Întrupării, acel fiat sau consimţământ dat la Bunavestire de Fecioara Maria (Lc. 1, 26-38). Ea este conştientă de rolul şi de destinul ei, pe care le acceptă cu răspundere şi cu bucurie (Lc. 1, 45-49). Un alt aspect, formulat în special la Sinodul de la Constantinopol din 681, este cel de parthenia, pururea fecioria Maicii Domnului. Comparată cu „rugul aprins care nu se mistuia” şi cu scara cerească pe care s-a pogorât Dumnezeu la om şi s-a suit omul la Dumnezeu, ea 1-a 
Mărturia prin calitatea şi sfințenia vieții este cel mai eficient mijloc de misiune. Pentru că nimic nu este mai atrăgător şi mai convingător decât creştinul, comunitatea sau sfântul, care oferă un exemplu concret de împlinire a sensului vieții şi iradiază linişte, pace şi iubire. Şi aceasta cu atât mai mult într-o societate care nu poate oferi o coerență şi un sens al vieții. Tendinței crescânde de secularizare nu i se poate opune cu eficiență decât alternativa exemplului unei vieți împlinite în comuniune cu Dumnezeu, căci „oricărui cuvânt i se poate opune alt cuvânt, dar vieții cine i se va împotrivi?". Chiar şi în perioada grea pentru Biserică, cum ar fi cea nazistă sau cea a presiunii comuniste atee, sfințenia nu a încetat să se manifeste, ceea ce înseamnă că „predarea” Bisericii în mâinile puterii seculare nu a fost totală ${ }^{16}$.

Eclesiologia ortodoxă posedă după părerea Părintelui Bria părere împărtăşită, de altfel, unanim de teologii ortodocşi - o profundă bază triadologică: toate Persoanele Treimii sunt active în viața Bisericii: „Această casă Tatăl a zidit-o, Fiul a întărit-o, Duhul

născut pe Iisus Hristos în chip minunat și mai presus de fire, prin puterea Duhului Sfânt (Lc. 1, 34-35), rămânând fecioară înainte, în timpul și după naștere. Un al treilea aspect se referă la Maria ca Născătoare de Dumnezeu (Theotokos). În fine, Fecioara Maria este și panaghia, ,cea plină de har” (Lc. 1, 28). „Umanitatea ei a fost sfințită de Dumnezeirea Cuvântului, prin sălăş̧luirea Acestuia în ea. Ea este plină de har din cauza acestei sălăşluiri. Ea s-a arătat ... mai înaltă decât toate făpturile cerești şi pământești, mai cinstită decât heruvimii și mai mărită decât serafimii, Doamnă și Stăpână". Reprezentând nu doar un model moral pentru oameni, ci şi concretizarea istorică a îndumnezeirii - fiind cea dintâi făptură umană sfințită nemijlocit de Iisus Hristos -, Maicii Domnului i se atribuie în Biserica Ortodoxă un cult de venerare. Acest cult de preacinstire a Maicii Domnului se întemeiază „atât pe contribuție ei la întruparea Fiului, cât şi pe mijlocirea şi pe ajutorul ei de maică a Bisericii, nedespărțită de Fiul". Vezi Ibidem, pp. 167-168.

${ }^{16}$ Idem, Martyre, în Ion Bria Philippe Chanson, Jacques Gadille, Marc Spindler (eds.), „Dictionnaire oecuménique de missiologie. Cent mots pour la mission”, Paris-Genève-Yaoundé, ed. du Cerf, Labor et Fides, CLE Yaoundé, 2001, pp. 196-199. Vezi de asemenea un alt volum editat de Păr. Bria, Martyria-Mission. The Witness of the Orthodox Churches today, Geneva, WCC Publications, 1980. 
Sfânt a înnoit-o". Biserica este opera Sfintei Treimi sau, altfel spus, are ca sursă însăşi comuniunea vieții Treimice. Nu este întâmplător că unii Sfinți Părinți nu vorbesc despre Biserică doar din momentul constituirii ei la Cincizecime; ea a fost prefigurată chiar de la creație şi pregătită sub Vechiul Legământ, deoarece are menirea să arate şi să comunice viața lui Dumnezeu ${ }^{17}$.

Referindu-se la mutațiile penticostale, la modificările eclesiale orizontale, Părintele Ion Bria scria: „Pe Cruce şi în Înviere, Biserica este nu numai răscumpărată, restaurată în comuniune cu Dumnezeu, dar devine părtaşă la Învierea Lui. Misiunea Lui continuă după Înviere. După ce a inaugurat Împărăția lui Dumnezeu, Iisus se arată şi trimite Duhul Sfânt la Cincizecime, ca să facă din Biserică trupul Său şi templul Duhului Sfânt" ${ }^{\prime 1}$. Biserica are o dimensiune universală, fiind menită a răscumpăra şi sfinții toate națiunile pământului. Ea este ,pârga sfântă a neamurilor” (Apoc. 14, 4), ceea ce dă un sens şi atributelor sau însuşirilor pe care ea le posedă: unitatea - Biserica este una deoarece Dumnezeu este unul, HristosCapul ei este unul, credința este una, Botezul este unul (Efes. 4, 4-6); sfințenia - provine de la Dumnezeu, de la Hristos-Unsul, consacrat şi slăvit ca Domn pe cruce, şi de la Duhul Sfânt, care pune ,pecetea ungerii" cu darul lui Dumnezeu pe toți cei botezați; universalitatea, catolicitatea sau sobornicitatea - are ca izvor tocmai relația Bisericii cu Sfânta Treime, fapt care o determină să posede plenitudinea mijloacelor de mântuire: doctrina Apostolilor, cultul sacramental, slujirea sacerdotală şi comuniunea frățească; apostolicitatea Biserica este apostolică deoarece este zidită pe piatra credinței Apostolilor: „Tu eşti Hristosul, Fiul lui Dumnezeu celui viu” (Mt. 16, 16). „Hristos Însuşi conduce Biserica prin Apostolii Săi, prezenţi în succesorii lor, episcopii consacrați prin hirotonie" 19 .

\footnotetext{
${ }^{17}$ Idem, Tratat de Teologie Dogmatică şi Ecumenică, București, Editura România Creștină, 1999, p. 158.

${ }^{18}$ Ibidem, p. 159.

${ }^{19}$ Vezi Ibidem, pp. 160-161.
} 
Deşi aflată în strânsă legătură cu toate atributele Bisericii, lucrarea misionară este cel mai mult legată de apostolicitate ${ }^{20}$. Biserica este zidită pe temelia profeților şi apostolilor „în sensul că misiunea apostolilor, ca martori direcți ai lui Hristos, trebuie să continue după dispariţia lor”. Apostolii răspund astfel la o chemare divină şi se bucură de trimitere la apostolat tot de origine divină, căci lucrarea lor se face potrivit voinţei lui Hristos Însuşi: „Precum M-a trimis pe Mine Tatăl, aşa vă trimit şi Eu" (In. 20, 21). La fel este cazul şi cu succesorii apostolilor. Ei sunt introduşi în slujba Bisericii printr-o lucrare de succesiune apostolică, printr-o taină specială numită Hirotonie. Deşi Biserica creştină în întregime se constituie ca un „corp sacerdotal”, în ea coexistă două preoții: una universală, a celor botezați (vezi I Pt. 2,4) şi una particulară sau specială, primită prin Taina Hirotoniei, cunoscând trei forme de slujire: episcop, preot şi diacon. După cum am mai precizat, şi această preoție este de drept divin: „Nimeni nu ia singur cinstea pentru sine, Duhul v-a pus episcopi, ca să păstoriți Biserica" (Fa. 20, 28). De asemenea, episcopul nu înlocuieşte pe Hristos, Care este prezent nevăzut în Biserică ,„̂n toate zilele până la sfârşitul timpului” (Mt. 28, 20). Episcopul are un rol esențial în viața Bisericii - el propovăduieşte Evanghelia, celebrează tainele şi păstrează unitatea Bisericii - dar numai în numele lui Hristos. Această viziune echilibrată a Bisericii Ortodoxe a împiedicat căderea în anumite extreme, cum ar fi infailibilitatea sau primatul episcopului Bisericii din Roma. Autoritatea fiecărui episcop nu presupune un primat jurisdicțional, de conducere; dimpotrivă, lucrarea sa de conducere se face doar în cadrul unui sinod - iar Sf. Ap. Petru şi urmaşul său, Papa de la Roma, posedă nu o autoritate specială peste ceilalți Apostoli ci printre ei, ca primus inter pares ${ }^{21}$.

\footnotetext{
${ }^{20}$ Idem, Credința pe care o mărturisim, p. 168; Idem, Dicționar de teologie ortodoxă, p. 35: „Vocația misionară a Bisericii ține de caracterul ei apostolic de apostolicitatea ei".

${ }^{21}$ Idem, Comentariu la catehismul ortodox, Sibiu, Editura „Oastea Domnului”, 2000, pp. 100-101, respectiv 102-103.
} 
Lucrarea misionară a Bisericii presupune două aspecte: pe de o parte, problema celor care au dreptul de a intra în Biserică, şi pe de altă parte, problema celor care desfăşoară lucrarea de atragere a oamenilor la Cuvântul Evangheliei. Prima problemă nu pune mari dificultăţi. Cine are dreptul să intre în Biserică şi prin ce mijloace a fost chestiunea dezbătută de Sinodul Apostolic din Ierusalim (50), unde s-a admis că nu doar membrii poporului ales ci şi păgânii pot intra în comunitatea creştină fără alte condiții decât credința şi Botezul. "Căci şi neamurilor le-a dat Dumnezeu pocăința spre viață" (Fa. 11, 18). Dumnezeul este Tatăl tuturor oamenilor (Rom. 3,29), şi astfel Biserica este deschisă tuturor, este ecumenică, adică destinată să cuprindă tot pământul (oekumene). Revelatoare este întâlnirea lui Iisus cu ofițerul roman în Capernaum. Sensul scenei este acesta: „Nimeni nu este exclus de la harul lui Dumnezeu. Acesta (sutaşul, n.n.) nu crede în miracole, nu-l aşteaptă pe Mesia, dar recunoaşte autoritatea lui Iisus, pe care-L roagă să spună cuvântul care să-1 vindece pe slujitorul său (Lc. 7, 1-9). Iisus recunoaşte, aici, credința care se găseşte chiar în afară de Israel şi de Biserică" ${ }^{\prime 22}$.

$\mathrm{Cu}$ referire la aceste aspecte, ca şi concluzii, subliniem încă o dată următoarele trei aspecte:

1) Biserica este condiția misiunii creştine, instrumentul misiunii şi, mai mult decât atât, scopul misiunii şi realizarea misiunii deoarece Biserica face parte din mesajul Evangheliei. Biserica este şi un rezultat al misiunii întrucât Dumnezeu conduce pe oameni la mântuire şi le dăruieşte harul său prin activitatea misionară a Bisericii.

2) Liturghia Euharistică rămâne izvor, model şi inspirație de viață socială. După cum detaliază Părintele Ion Bria, ,roadele creației şi ale muncii credincioşilor sunt oferite la altar şi schimbate în daruri euharistice, ca să fie apoi împărtăşite tuturor ca forțe de comuniune. Dumnezeu este generos şi îi invită pe toți la masa de nuntă, cu condiția ca cei invitați să devină exemplu de convivialitate şi de solidaritate cu semenii lor. Ritual unic de comuniune mintală şi

${ }^{22}$ Idem, Tratat de teologie dogmatică şi ecumenică, p. 161. 
afectivă, Liturghia este capabilă să refacă toate relațiile umane, nu numai cu Dumnezeu, în mod abstract, ci şi cu comunitatea socială, $\mathrm{cu}$ familia şi societatea. Liturghia şi diaconia sunt deci inseparabile" ${ }^{23}$.

3) Lucrarea misionară, împlinirea cerințelor pe care le reclamă „Liturghia după Liturghie”, îi vizează deopotrivă pe clerici şi pe laici. Ion Bria a subliniat în repetate rânduri că desfăşurarea activității misionare a Bisericii nu este apanajul exclusiv al unor specialişti. Mai mult decât atât, fiecare preot se cuvine să-şi exercite în mod deosebit lucrarea misionară. Fiecare preot „trebuie să fie pe deplin purtătorul Veştii celei Bune a Învierii". Atitudinea sa trebuie să fie adaptată la schimbările societății contemporane. El nu mai poate rămâne pasiv şi fatalist. Informat în legătură cu noile cerințe ale vremii, el este chemat să predice Evanghelia nu doar prin cuvânt, ci prin întreaga sa viață.

\section{Bibiografie:}

1. Biblia sau Sfânta Scriptură, tipărită sub îndrumarea și cu purtarea de grijă a Prea Fericitului Părinte Teoctist, Patriarhul Bisericii Ortodoxe Române cu aprobarea Sfântului Sinod, București, EIBMBOR, 1988.

2. Bria, Ion, Mărturia creştină în Biserica Ortodoxă: aspecte, posibilități şi perspective actuale, în „Glasul Bisericii”, anul XLI, nr. 1-3, 1982, pp. 70109.

3. Idem, Dicționar de Teologie Ortodoxă, Ediția a II-a, Bucureşti, EIBMBOR, 1994.

4. Idem, Ortodoxia în Europa. Locul spiritualității române, Iaşi, Editura Trinitas, 1995.

5. Idem, „Spre plinirea Evangheliei”. Dincolo de apărarea Ortodoxiei: exegeza şi transmiterea Traditiei, Alba Iulia, Editura Reîntregirea, 2002.

6. Idem, Destinul Ortodoxiei, București, EIBMBOR, 1989.

7. Idem, Credința pe care o mărturisim, București, EIBMBOR, 1987.

8. Idem, Martyre, în Ion Bria Philippe Chanson, Jacques Gadille, Marc Spindler (eds.), ,Dictionnaire oecuménique de missiologie. Cent mots pour la mission", Paris-Genève-Yaoundé, ed. du Cerf, Labor et Fides, CLE Yaoundé, 2001.

${ }^{23}$ Idem, Liturghia după Liturghie. Misiune apostolică şi mărturie creştină $a z i$, București, Editura Athena, 1996, p. 126. 
9. Idem, Tratat de Teologie Dogmatică şi Ecumenică, București, Editura România Creștină, 1999.

10. Idem, Comentariu la catehismul ortodox, Sibiu, Editura „Oastea Domnului", 2000.

11. Idem, Liturghia după Liturghie. Misiune apostolică şi mărturie creştină azi, București, Editura Athena, 1996.

12. Idem, Studii de Misiune şi Ecumenism, Sibiu, Editura, Astra Museum, 2013.

13. Yannoulatos, Archbishop Anastasios, Mission in Christ's Way. An Orthodox Understanding of Mission, Brookline/Geneva, Holy Cross Orthodox Press/World Council of Churches Publications, 2010. 